\title{
A critical analysis of methods for rapid and nondestructive determination of wood density in standing trees
}

\author{
Shan $\mathrm{Gao}^{1} \cdot$ Xiping Wang ${ }^{2}$ - Michael C. Wiemann ${ }^{2} \cdot$ Brian K. Brashaw ${ }^{2}$. \\ Robert J. Ross ${ }^{2} \cdot$ Lihai Wang ${ }^{1}$
}

Received: 2 September 2016 / Accepted: 14 February 2017 / Published online: 22 March 2017

(C) INRA and Springer-Verlag France 2017

\begin{abstract}
- Key message Field methods for rapid determination of wood density in trees have evolved from increment borer, torsiometer, Pilodyn, and nail withdrawal into sophisticated electronic tools of resistance drilling measurement. A partial resistance drilling approach coupled with knowledge of internal tree density distribution may offer an alternative solution for wood density surveys in the future.

- Context Finding ways to nondestructively assess wood density in trees has been a quest by foresters and wood scientists around the world. In the past several decades,
\end{abstract}

Contribution of the co-authors

This work is the result of research collaborations between the Northeast Forestry University (China) and the USDA Forest Products Laboratory (USA).

Dr. Shan Gao conducted the literature review, synthesized the information, and wrote the draft manuscript.

Dr. Xiping Wang supervised the work, revised the manuscript, and wrote part of the manuscript.

Dr. Michael C. Wiemann reviewed and wrote part of increment core section.

Dr. Brian K. Brashaw initiated the project and reviewed the manuscript. Dr. Robert J. Ross coordinated the project and reviewed the manuscript. Dr. Lihai Wang coordinated the project and reviewed the manuscript.

Handling Editor: Jean-Michel Leban

Shan Gao

gaoshan_2000@126.com

Xiping Wang

xwang@fs.fed.us

Michael C. Wiemann

mwiemann@fs.fed.us

Brian K. Brashaw

bbrashaw@fs.fed.us traditional increment borer methods have gradually evolved into sophisticated electronic tools of resistance drilling measurements.

- Aims We provide a comprehensive review of research development in the use of several field nondestructive methods for rapid determination of wood density in trees and discuss pros and cons of each method for field applications.

- Results The use of the increment borer has been a standard method for assessing wood density in trees, and it has been further developed into a system approach allowing the use of outer wood cores and knowledge of internal density distribution for predicting wood density of major tree components. Studies on the use of torsiometer, Pilodyn, and nail withdrawal tools have had very limited success and do not warrant replacement of the increment borer. Resistance drilling, on the other hand, has emerged as a potential tool for more efficient and economical collection of wood density information in trees.

- Conclusion The resistance drilling method has considerable advantages over other methods in terms of less damage to trees, faster operation, and higher measurement sensitivity. Internal friction is a key factor that currently hinders further application.

Robert J. Ross

rjross@fs.fed.us

Lihai Wang

lihaiwang@yahoo.com

College of Engineering and Technology, Northeast Forestry University, Harbin, Heilongjiang 150040, China

2 USDA Forest Service, Forest Products Laboratory, Madison, WI 53726-2398, USA 
Keywords Increment borer $\cdot$ Increment core $\cdot$ Nail withdrawal $\cdot$ Pilodyn $\cdot$ Resistance drilling $\cdot$ Torsiometer

\section{Introduction}

Density is one of the important wood characteristics of standing trees that affect the properties and performance of various wood products, such as sawn timber, reconstituted products, and pulp and paper (Blair et al. 1976; Zhang 1997; Zobel and van Buijtenen 1989). Wood density has been considered a quality trait in tree improvement programs because of its economic value and high degree of genetic control (Sprague et al. 1983); it is a fundamental component of biomass determinations in ecosystem studies and is a cornerstone of functional trait analysis in community ecology (Wiemann and Williamson 2013). Wood density is highly variable, particularly within and between individual trees in forests. The within-tree variation constitutes a major part of the overall variability, and it has been well documented for some commercial species (Kandeel and Bensend 1969; Wiemann and Williamson 2014; Tian et al. 1995; Kimberley et al. 2015).

Wood density is the weight per volume, which includes the weight of water contained by the wood, whereas specific gravity is the density of oven dry wood relative to the density of water. Weight of wood varies with moisture content, and volume of wood varies with moisture content below wood's fiber saturation point (Glass and Zelinka 2010; Williamson and Wiemann 2010). Therefore, it is important to specify moisture content when using density or specific gravity values. When living trees are tested for density, it is reasonable to assume that the moisture content is above fiber saturation and that "green" values are the metric being considered. That is the assumption of this paper.

The traditional technique for determining wood density in standing trees is to extract increment cores from trees and measure their volume and mass of wood in a laboratory (Cown 2006; Wiemann and Williamson 2013). Although this method is relatively easy and accurate, it is time consuming and labor intensive for wood quality surveys or genetic improvement programs that require extensive density analyses. Even so, since its invention in the mid-1800s (Pressler 1866), the increment borer has been the primary tool for "nondestructive" sampling of standing trees. Nondestructive is a relative term, because damage is done whenever the protective covering of bark is compromised; the term is used in comparison with sampling methods that require the felling of trees.

Another technique capable of providing highly accurate wood density measurement is x-ray densitometry. This technique also uses increment cores. Advantages are its ability to clearly obtain wood density values in different biological zones and allow for densitometry comparisons between radii within the same tree, between trees on the same site, and between mean density values at different sites (Cown 1981; Cown and Clement 1983; Eberhardt and Samuelson 2015). However, the x-ray method requires careful sample preparation and data analysis and can only be carried out in laboratory. It does not satisfy the requirements for a rapid and economical evaluation of wood density in standing trees.

For the purpose of achieving rapid, reliable, and economical wood density measurements in standing trees without using increment borers, other nondestructive methods and field instruments have been evaluated by many researchers. These include the torsiometer, Pilodyn wood tester, nail withdrawal, and resistance drilling tools. In this paper, we provide a comprehensive review of the principles of these field nondestructive methods and their use in various studies for determining wood density in standing trees, discuss pros and cons of each method for field applications, and identify the technical challenges that need to be overcome in future research. This paper is based on a previous presentation (Gao et al. 2012), with significant revisions and additions.

\section{Increment coring}

An increment borer is the primary tool used to extract cores from living trees for analysis of growth trends based on inspection of the tree's ring patterns (Fig. 1). The tool was originally developed in Germany ca. 1855 (Pressler 1866) and has changed little since its original design (Schweingruber 2001; Grissino-Mayer 2003). The tool consists of a handle, an auger bit, and a small half-circular metal tray (the core extractor) that fits into the auger bit. Increment borers come in various diameters ranging from 4.3 to $12 \mathrm{~mm}$, and lengths ranging from 100 to $700 \mathrm{~mm}$ in increments of $50 \mathrm{~mm}$, although lengths up to $1000 \mathrm{~mm}$ can be specially ordered (Grissino-Mayer 2003). The borer diameter determines the diameter of the increment core. Details on proper use, care, and maintenance of an increment borer are described in Grissino-Mayer 2003. When cores have been cut and extracted from trees, they need to be put into suitable containers and transported to a laboratory where wood density or specific gravity can be determined by measuring the green volumes and oven dry mass of the complete cores or segments of them.

For many years, the increment borer has been used as a simple nondestructive tool to evaluate wood quality of forest resources. A range of wood properties including basic density, fiber length, and microfibril angle can be obtained from increment cores taken from standing trees (Downes et al. 1997). Early research work conducted at the USDA Forest Products Laboratory indicated that a single conventional increment core, taken at tree breast height, can be used to estimate the average specific gravity of both the adjacent wood (the nearest disk) and the merchantable portion of a southern yellow pine tree (Paul and Baudendistel 1956; Wahlgren and Fassnacht 


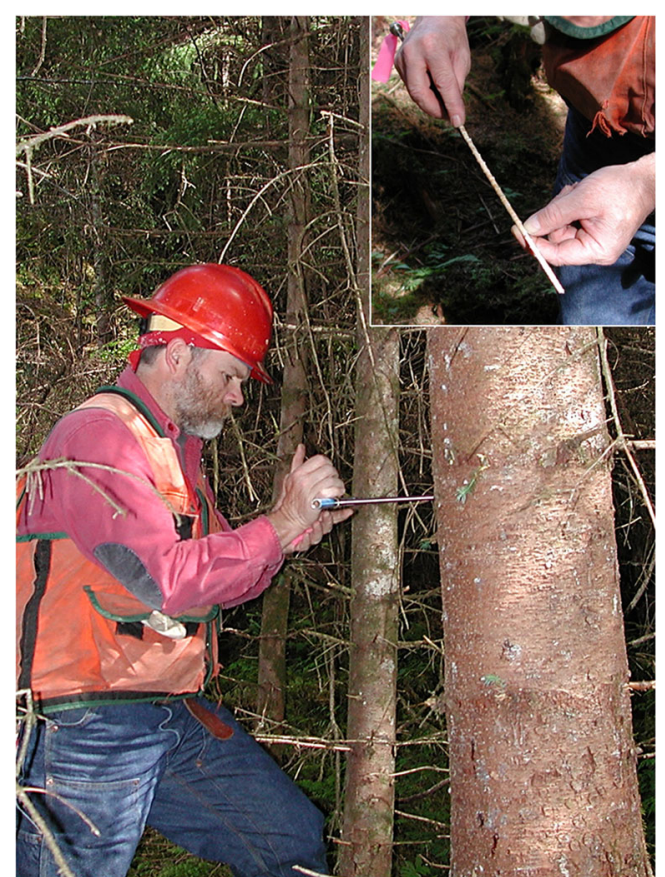

Fig. 1 Increment borer being used to extract a core sample from a tree at breast height (photo credit: Xiping Wang)

1959; Taras and Wahlgrn 1963). The increment core method was compared closely in accuracy with standard methods of determining specific gravity in wood specimens of limited size by Paul and Baudendistel (1956).

Reliable estimates of tree density or specific gravity are derived from cores that extend from bark to pith because they reveal the full extent of radial variation. Unfortunately, boring trees from bark to pith is often difficult and replete with problems. Some of these challenges, as previously encountered by foresters and dendrochronologists (Maeglin 1979; Jozsa 1988; Grissino-Mayer 2003), are as follows: (1) Trees are too large for the borer to reach the pith; (2) the borer misses the pith, passing to the side of it; (3) borers are difficult to insert in trees with dense wood; and (4) borers are difficult to extract, for multiple reasons.

Given the problems of bark-to-pith boring, alternative partial sampling techniques have been developed for estimating tree density even when radial variation is substantial. Williamson and Wiemann (2010) suggested a novel approach, based on stem geometry, to sample only the wood that approximates the density of a whole disk. The concept is that, if a function describing the radial variation in density is known, then it can be used to determine the point along the radius at which the wood density equals the area-weighted density. In theory, the tree need only be bored to that point, to estimate density of the whole cross section. For radial changes that are linear, the point of approximation falls at two thirds of the wood radius; i.e., the wood density at two thirds of the distance from pith to bark should equal the density of the whole disk (Williamson and Wiemann 2010). In application of this method, the point one sixth of the diameter inward from the bark/xylem interface would be used to correspond to two thirds of the distance from the pith outward. This method has been proven successful for trees with linear (or no) changes in density across the radius (Wiemann and Williamson 2012a, b, 2013). The usefulness of the method for estimating the wood density of a species is conditional on knowledge of the pattern of radial change in density and the degree of eccentricity in the species (Wiemann and Williamson 2012b; Williamson and Wiemann 2010).

In New Zealand, extensive wood density surveys were carried out on radiata pine (Pinus radiata D. Don) resources by extracting partial cores at breast height. The survey results indicated a good relationship between outer wood density and whole-tree density. An empirical model called STANDQUA was developed in the mid-1990s that enabled within-tree patterns of radiata pine wood density to be estimated from breast-height core samples and the future log-level wood density to be predicted (Tian and Cown 1995; Tian et al. 1995). More recently, a comprehensive wood density model was developed for radiata pine using an extensive wood density dataset (from breast height increment cores and stem disks) collected over 50 years of research to predict withintree, within-stand, and among-stand variation in wood density (Palmer et al. 2013). The model can be used to predict the density of disks or logs cut from any position within a tree and can utilize measured outer wood density values to predict the density, by log height, for a particular stand. It can further be used in conjunction with outer wood density to predict wood density distributions by logs for stands of any specified geographic location and management regime (Kimberley et al. 2015). Many forest growers in New Zealand today routinely collect breast height outer wood cores as part of their preharvest assessments.

Since the 1990s, there has been a steady increase in the development of tools for nondestructive assessment of wood quality in trees prior to harvesting. One significant development has been the SilviScan system that utilizes x-ray diffraction, $\mathrm{x}$-ray densitometry, and image analysis to measure a range of wood properties from one increment core (Evans and Ilic 2001; Evans and Kibblewhite 2002). Wood density, stiffness, microfibril angle (MFA), and tracheid properties such as tracheid diameter, coarseness, and cell wall thickness can all be measured. All SilviScan data can be related to individual annual rings so that detailed "tree property maps" can be developed, allowing quantification of the effects of site, silvicultural treatment, or genotype. There are three SilviScan units in operation now (in Australia, Sweden, and Canada), providing services to many users around the world.

Another example is the development and commercialization of standing tree acoustic tools for assessing wood stiffness in trees (Wang et al. 2001, 2007a; Carter et al. 2005, 2013). Field-ready acoustic tools are now being used in industry to 
sort and grade trees for optimizing the wood uses and increasing profitability (Wang et al. 2007b). However, one of the challenges in predicting wood stiffness of standing trees is the lack of green wood density information, because dynamic modulus of elasticity is dependent of both acoustic velocity and green density. Based on increment core measurements, Chan et al. (2010) developed a protocol for determining green wood density and moisture content in plantation-grown radiata pine. The protocol requires separate processing of sapwood and heartwood and soaking the sapwood for $24 \mathrm{~h}$ to replace the moisture lost while coring. The data showed that $12-\mathrm{mm}$ increment cores removed from breast height proved to be a reliable method for predicting green density, saturation percentage, proportion of sapwood and heartwood, and number of heartwood rings as measured destructively by disks or wedges in radiata pine. However, the procedures still involves extensive laboratory work and analysis.

\section{Measurement with torsiometer coupled with increment coring}

The torsiometer is a handheld device designed to measure torque as a borer is driven into wood. The method of measuring wood density in standing trees using a combination of torsiometer and increment borer was originally proposed by Polge and Keller (1970), and early investigations relating the torque required to drive an increment borer to a known depth in a tree trunk were reported on by Polge and Keller (1970), Nicholls and Roget (1977), and Young (1977). This method still involves using an increment borer in the field, but essentially eliminates laboratory work. In field measurement, a bark window is cut and the boring operation is initiated using a starting handle. The torsiometer is then fit to the square end of the borer. The borer is rotated steadily through either a complete revolution or a complete revolution plus an additional $45^{\circ}$, while observing the torsiometer reading (Fig. 2). Typically a $5-\mathrm{mm}$ borer and a penetrating depth of $38 \mathrm{~mm}$ are specified for field applications (Nicholls 1985).

Our literature search yielded limited data on the use of the torsiometer on standing trees. The first research work on this method was conducted by Polge and Keller (1970), and their field test was conducted on 40-year-old grand fir (Abies grandis (Dougl.) Lindl.) and Douglas fir (Pseudotsuga menziesii (Mirb.) Franco) with encouraging results $(r=0.95)$. This method was subsequently evaluated by Harris et al. (1976) and Young (1977) on young radiata pines with mixed results $(r=0.74$ reported by Harris et al. and $r=0.94$ reported by Young). In Australia, Nicholls and Roget (1977) carried out a series of field tests on both juvenile and mature radiata pine trees (ranging from 8 to 37 years old) to ascertain the relationship between torsiometer readings and basic densities of increment cores. The strength of these

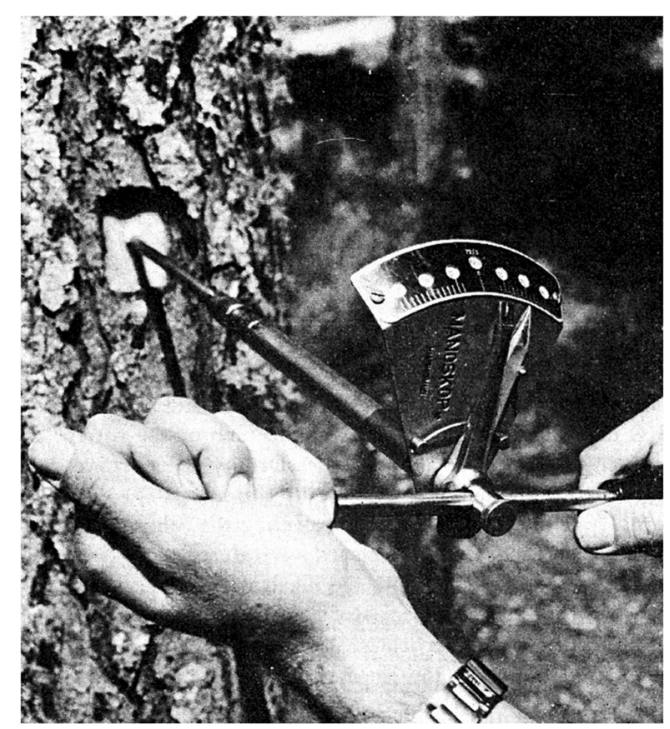

Fig. 2 Torsiometer attached to an increment borer bit (from Cown 1978, with permission)

correlations $(r=0.93-0.95)$ was comparable to those reported by Polge and Keller (1970). The trials showed that a torsiometer reading can provide an estimate of wood density accurate to within $\pm 8.7 \%$, at the $95 \%$ confidence level. However, according to Nicholls (1985), this degree of precision could not be duplicated in Canberra on radiata pine or in Queensland on slash pine (Pinus elliottii Engelm.) and Caribbean pine (Pinus caribaea Morelet). There was no evidence of any difference in the relationship between torsiometer reading and basic density within the range of age classes tested ( 8 to 37 years old). Trials in New Zealand on 10and 31-year-old radiata pine trees produced moderate correlations, with the correlation coefficients of 0.78 and 0.79 , respectively (Cown 1978).

\section{Pilodyn testing}

The Pilodyn Wood Tester (hereafter called Pilodyn) is a handheld instrument that was originally developed in Switzerland to collect quantitative data on the degree of soft rot in wooden poles (Cown 1978). The Pilodyn test involves injecting a spring-loaded pin into the wood and reading the depth of needle penetration from a scale on the body of the instrument (Fig. 3). Wood failure caused by the pin is a complex mixture of tension and compression failures parallel to and perpendicular to the grain, which is similar to the traditional destructive shock resistance tests (Hoffmeyer 1978). The Pilodyn instrument has three standard striker pins for field testing: $6 \mathrm{~J}$ (2.0$\mathrm{mm}$ diameter pin), $18 \mathrm{~J}$ (2.5-mm diameter pin), and $18 \mathrm{~J}$ (3.0$\mathrm{mm}$ diameter pin) ("J" stands for "joule" which is a measure of the force driving the pin) (Sprague et al. 1983). The use of the Pilodyn in standing trees requires removal of a bark patch, 


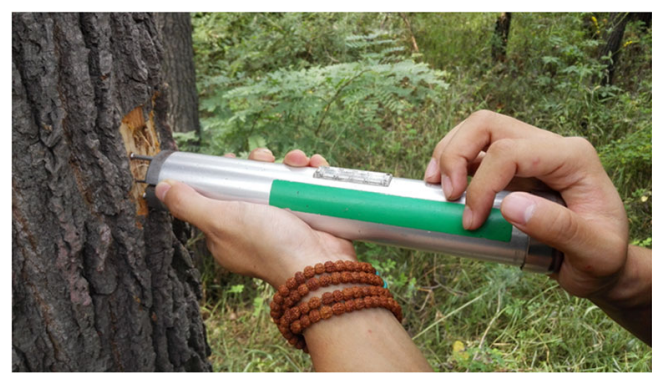

Fig. 3 The Pilodyn Wood Tester measuring the depth of needle penetration into the wood (photo credit: Shan Gao)

followed by driving the pin into the wood by a preloaded spring with a known force. The depth of pin penetration is directly correlated to wood density of the tree being tested.

Early studies on the use of the Pilodyn focused on the inspection of utility poles (Henningsson et al. 1976; Bagge 1977; Hoffmeyer 1978). The Pilodyn method was rated favorably as a "soft rot detector" when compared with alternative methods such as poking and inspection of increment cores (naked eye or microscopy). The tool was quickly adopted by some power companies in Sweden and Denmark in their routine pole inspection. Some of the advantages of the Pilodyn instrument are the following: (1) no skilled labor is necessary; (2) it takes into account not only the degree of decay but also the natural density (strength) of the wood; and (3) it provides quantitative data.

The utility of the Pilodyn to assess wood density of standing trees was recognized by Bagge (1977). He carried out a field experiment on 51 European silver fir (Abies alba Mill.) trees using a Pilodyn with a standard pin ( $6 \mathrm{~J}, 2.5 \mathrm{~mm}$ diameter pin). The pin penetrations were recorded without removing the bark, and the density of increment cores from the immediate vicinity of Pilodyn penetration was measured. The result showed a negative correlation $(r=-0.71)$ as the resistance to penetration through the bark layer was originally assumed negligible. After taking into account the resistance to penetration through the bark layer (assuming equivalence to the resistance to penetration of wood with a density of about $200 \mathrm{~kg} / \mathrm{m}^{3}$ ), a correlation coefficient of -0.80 was obtained. This is considered acceptable given the rather narrow density range of the tree samples $\left(320-480 \mathrm{~kg} / \mathrm{m}^{3}\right)$. Following this preliminary study, the use of the Pilodyn has been investigated extensively for its effectiveness in density prediction in trees.

Hoffmeyer (1978) reported that a series of laboratory tests were conducted at the Building Materials Laboratory at the Technical University of Denmark in order to establish relationships between Pilodyn pin penetration, Pilodyn energy, pin diameter, and basic wood density. The results showed a linear relationship between Pilodyn energy and penetration, and a parabolic relationship between pin diameter and penetration, which supports the speculation that part of the Pilodyn energy is spent on compression perpendicular to grain of fibers at the tip of the blunt pin. Cown (1978) further examined the relationship between penetration depth of a standard Pilodyn (6 J, 2.5-mm diameter pin) and wood density of the increment cores for 10-year-old radiata pine clones. The results of Pilodyn were also compared with those of the torsiometer method with regards to the accuracy for predicting wood density. The Pilodyn regression line accounted for $92 \%$ of the observed variation $(r=-0.96)$ compared to $61 \%$ $(r=0.78)$ for the torsiometer. For Pilodyn operation, there was a suspicion that pin penetration might be affected by the number of latewood bands encountered, as latewood density in radiata pine is appreciably greater than that of the earlywood, and the contrast increases with distance from the pith (Cown 1978). In another field trial in a 31-year-old radiata pine plantation, Cown (1978) tested the suitability of the Pilodyn method for assessing tree density in older stands. The results showed a better correlation between pin penetration and wood density $(r=-0.74)$ compared to the Torsiometer method $(r=0.62)$. In terms of ranking the individual trees by density with the Pilodyn and torsiometer results, Cown (1978) concluded that ranking by Pilodyn was more closely related to density trends than ranking by a torsiometer.

Correlations between Pilodyn penetration and wood density have also been reported by Cown (1979) for radiata pine $(r=-0.86)$, Norway spruce (Picea abies) $(-0.90)$, western red cedar (Thuja plicata Donn) $(-0.85)$, eastern white pine (Pinus strobus L.) $(-0.84)$, and European larch (Larix decidua Mill.) (-0.83), by Taylor (1981) for loblolly pine (Pinus taeda L.) $(-0.81)$, and by Micko et al. (1982) for white spruce (Picea glauca (Moench) Voss) (-0.83). As for the variance of Pilodyn penetration, significant differences were found in penetration values among trees and from side to side of the same tree (Taylor 1981). Side-to-side variation indicated that wood density differs from point to point around the circumference of a stem. Therefore, the accuracy of Pilodyn penetration readings to determine wood density of individual trees would be enhanced by taking multiple readings around the stem rather than multiple readings on one side.

There is also considerable evidence that Pilodyn penetration has a strong genetic correlation with wood specific gravity. In a heritability study, Sprague et al. (1983) evaluated three types of Pilodyn pins for their efficiency as an indirect selection method to improve mature wood-specific gravity in loblolly pine (P. taeda). In this investigation, wood properties influencing Pilodyn penetration had a strong genetic correlation with wood-specific gravity for two of the three Pilodyn pins tested $(r=-0.89$ for the 6-J 2.0-mm pin; $r=-0.82$ for the 18-J 3.0-mm pin; $r=-0.24$ for the $18-\mathrm{J} 2.5-\mathrm{mm}$ pin). Of the 
three Pilodyn pins tested, the $18-\mathrm{J} 3.0-\mathrm{mm}$ pin gave the highest relative efficiency $(83.6 \%)$ compared to direct selection for mature wood-specific gravity. Although gains would be greater for direct selection, the time and cost required to process thousands of increment cores in a laboratory make intensive direct selection for wood-specific gravity expensive. Sprague et al. (1983) suggested that the use of Pilodyn in selecting for mature wood-specific gravity would result in savings in time and money in comparison to extracting and processing increment cores. Similarly, a strong genetic correlation of Pilodyn penetration with wood-specific gravity was obtained for slash pine (P. elliottii) (Gough and Barnes 1984), Douglas fir (P. menziesii) (King et al. 1988), and Eucalyptus (da Rosado et al. 1983; Moura et al. 1987; Dean et al. 1990; Greaves et al. 1996; Wu et al. 2010).

\section{Nail withdrawal resistance measurement}

It has long been accepted that the resistance of a nail shank to direct withdrawal from a piece of wood is intimately related to the density or specific gravity of the wood, the diameter of the nail, and the depth of penetration (FPL 1965). An empirical equation for nail withdrawal resistance has been developed for bright common wire nails driven into the side grain of seasoned or unseasoned wood that remains wet. Although the nail withdrawal test is a common method to evaluate the fastening performance (holding power) in dry wood, its direct use in standing trees is very rare. Nicholls (1985) described a withdrawal resistance measuring apparatus in which hydraulic pressure is used to extract the nail, and the maximum value is used as a measure of the maximum withdrawal force. The equipment comprises the hydraulic cylinder, the nail holder, and a hand-operated pump coupled with a pressure gauge, which is fitted with the resettable maximum-value indicator (Fig. 4a). In operation, a $30 \times 70-\mathrm{mm}$ window is cut in the bark of the tree and the nail is hammered into the exposed xylem in the center of the bark window. Care should be taken to drive the nail radially into the wood so that it is not bent during extraction. The pump is operated to produce a steady increase of hydraulic pressure until the maximum pressure is indicated. This value is recorded, and further pumping enables the nail to be withdrawn completely from the tree. The maximum withdrawal resistance of the nail typically occurs after a small nail displacement (Fig. 4b).

Nicholls (1985) reported on the use of a nail withdrawal apparatus for determining wood density in radiata pine, white cypress pine (Callitris glauca R. Br.), and 16 species of Eucalyptus growing in Victoria, Australia. The concept of the method is based on the mechanism involved in the nail withdrawal process, that is, the resistance to withdrawal of a nail is caused by the frictional constraint due to the lateral forces acting normal to the surface of the nail. These lateral forces are believed to vary with the density of the wood. Consequently, there should be a positive relationship between the maximum force required to withdraw a nail driven into the tree and the wood density of the tree. Nicholls evaluated this testing method through more than 30 tests involving 600 trees with a density range of $330-870 \mathrm{~kg} / \mathrm{m}^{3}$. He found that the nail withdrawal behavior in trees is affected by species, wood density, nail type, nail diameter, and surface condition of the nail. The force-displacement curves for nail penetration and withdrawal showed similar patterns for the three species and two different nail diameters ( 2 and $4 \mathrm{~mm}$ ) investigated in the study. Figure $4 \mathrm{~b}$ illustrates a typical force-displacement curve for penetration and withdrawal of a nail in freshly cut wood at a loading rate of $20 \mathrm{~mm} / \mathrm{min}$ (Nicholls 1985). The force increased linearly to the point of maximum penetration, and then, as the withdrawal process started, the force decreased exponentially due to a relaxation effect. Maximum withdrawal force was observed to occur following either a very small displacement of the nail or after an irregular
Fig. 4 Nail withdrawal resistance measuring device. a Apparatus using hydraulic means to extract the nail and measure the maximum withdrawal force. $\mathbf{b}$ Typical force-deflection curve for penetration and withdrawal of a nail in green wood (from Nicholls 1985, with permission)

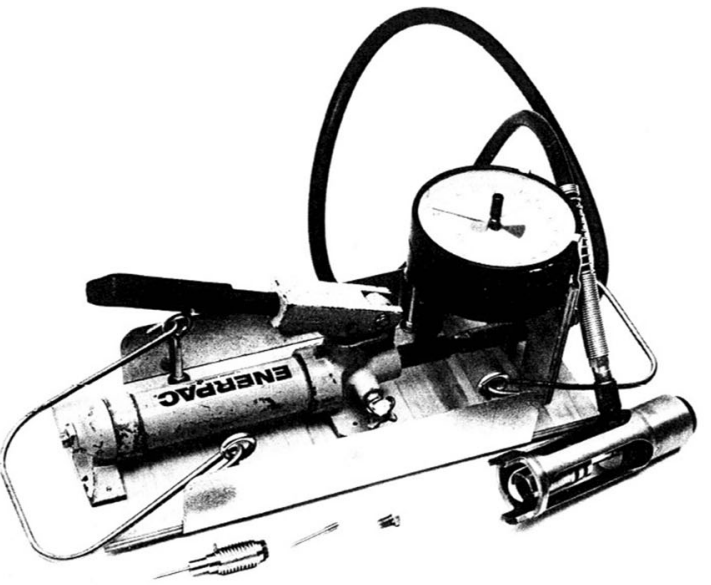

a)

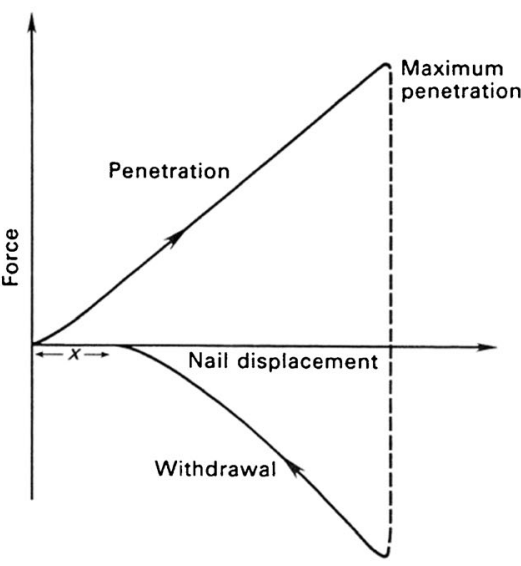

b) 
increase in force over a comparatively long period of withdrawal. Nicholls (1985) also identified some drawbacks of the round section nails, such as causing splits in pine wood and permanent deformation in eucalypts. The cylindrical nail was found suitable for the low-density trees such as pines ( $r=0.91$ between force and density), whereas the nail of the elliptical cross section yielded the best results for testing denser wood $(r=0.92)$.

\section{Resistance drilling measurement}

The resistance drilling tool is a mechanical drill system that measures the relative density profile as a rotating drill bit is driven into wood at a constant speed. Figure 5 shows the use of a resistance drill (Resistograph $($ ) $)$ in a standing tree to obtain the relative resistance profile. The technique operates on the principle that drilling resistance (torque) is directly related to the density of the material being tested (Rinn 1988, 1989, 1990; Rinn et al. 1996). During the process of a drilling measurement, the relative drilling resistance, feeding force, and speed parameters can be measured continuously as a function of the drill bit position in the drilling path (Mattheck et al. 1997). A resistance drilling tool typically consists of a power drill unit, a small-diameter spade-type drill bit, and an electronic device that can be connected to the serial interface input of any standard personal computer. As the drill bit moves through the wood in a linear path, the penetration resistance along its path is measured and recorded. The pattern of change in relative resistance is recorded as a digital representation display.

The first prototype of the resistance-based drilling machine was developed by Kamm and Voss in 1984 employing a

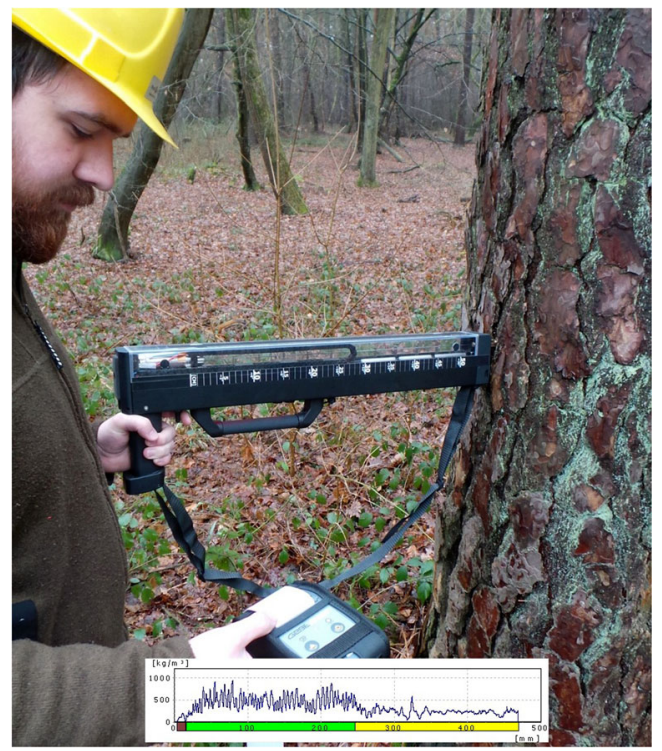

Fig. 5 Electronically regulated resistance drilling in a standing tree using a Resistograph ${ }^{\circledR}$ tool (photo credit: Frank Rinn) spring-loaded recording mechanism (Rinn 2012). The resonance effects of the spring mechanism were later found to lead to inaccurate readings and profiles. A study conducted at Hohenheim University and the Environmental Physics Institute of Heidelberg University made a breakthrough in the resistance drilling concept and proved that electronic regulation and electronic recording of the motor power consumption could achieve much more reliable and repeatable resistance profiles than the spring-loaded mechanism (Rinn 1988, 2012). Additional experiments demonstrated that when the needle's tip was flat and twice the diameter of the shaft, the measured electrical power consumption (EPC) was proportional to the mechanical torque at the needle, and it mainly depended on the local density at the point of contact of the drill bit (Rinn 1989, 1990). After thousands of tests, a shaft diameter of $1.5 \mathrm{~mm}$ and a 3-mm-wide tip was found to be a good compromise between minimizing damage and maximizing information in the profiles (Rinn 1989, 1990, 2012). With this breakthrough and new electronic improvements, the Resistograph ${ }^{\circledR}$ tool can now simultaneously measure, display, and record the relative resistance profile through direct measurement of the EPC of a direct-current, needle-rotation motor while a drill bit is driven into the tree.

A significant amount of research has been conducted to explore the use of resistance drilling measurements for various applications such as tree ring analysis (Rinn et al. 1996; Chantre and Rozenberg 1997; Wang and Lin 2001; Wang et al. 2003; Saez et al. 2008; Guller et al. 2012; Helms and Niemz 1994), tree decay detection (Wang and Allsion 2008; Allison and Wang 2015), and structural timber condition assessment (Rinn 1990, 2012; Ceraldi et al. 2001; Ross et al. 2004). Rinn et al. (1996) demonstrated that Resistograph charts of coniferous and deciduous wood reveal tree ring variations. Figure 6 shows an example of a drilling profile obtained from Norway spruce (P. abies) revealing density variations inside tree rings caused by earlywood and latewood zones. Note that the extremely dry summer of 1976 can be identified by the corresponding narrow ring in the center. In the ideal case of drilling in the radial direction (perpendicular to the growth rings), the tree ring parameters in dry wood revealed by Resistograph charts showed excellent matches with those revealed by the x-ray density charts, both qualitatively and quantitatively (Fig. 7). Chantre and Rozenberg (1997) compared Resistograph measurements with

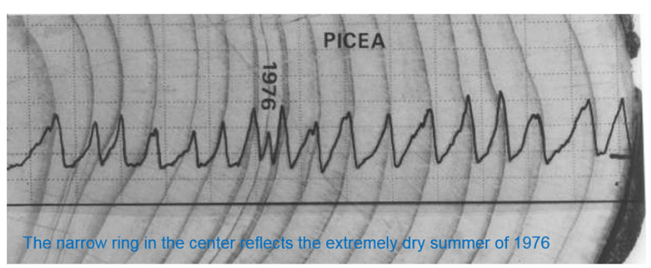

Fig. 6 Resistance drilling profile obtained from a Norway spruce (Picea abies) revealing density variations inside tree rings (from Rinn et al. 1996, with permission) 


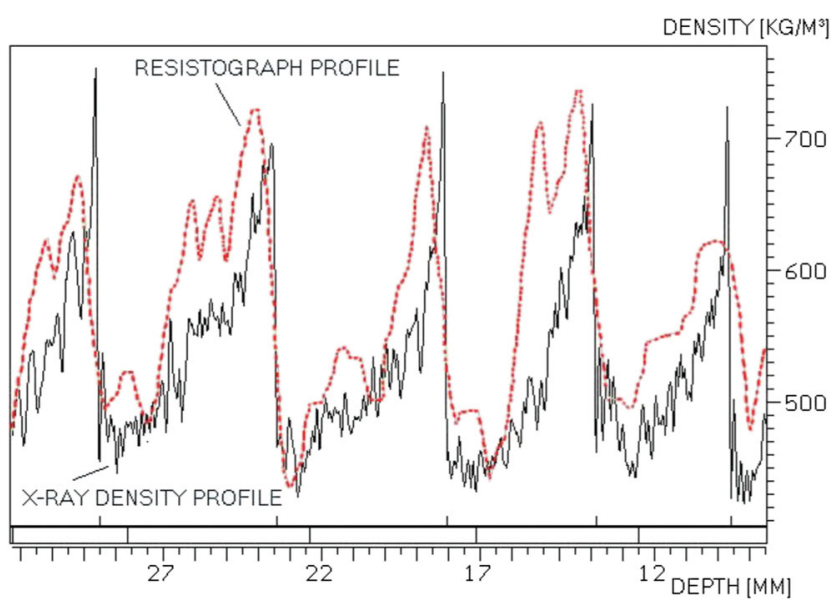

Fig. 7 Resistograph chart of Tilia platyphyllos superposed with its radial $\mathrm{X}$-ray density profile (resolution: $1 / 100 \mathrm{~mm}$ ). The tree ring variations in the resistance profile are very similar to those in $\mathrm{x}$-ray profile. The resistance variations are about as sensitive, but the local resolution is less pronounced (from Rinn et al. 1996, with permission)

microdensitometry (MDM) on disks cut from 23-year-old Douglas fir trees and found moderate to excellent correlations between profile parameters (profile surface, profile energy, and mean density of the weighed profile) ( $r$ from 0.93 to 0.97). They concluded that the Resistograph seems better adapted to the evaluation of some whole trunk parameters, able to sum up in a single value one aspect of the standing tree global wood quality. Wang and Lin (2001) reported that the resistance drilling profile in Taiwania (Taiwania cryptomerioides Hayata) plantation wood revealed density variations inside tree rings caused by earlywood and latewood zones. The technique was also found useful in examining the effects of silvicutural treatments on density profiles and annual ring characteristics (Wang et al. 2003).

Research has quickly progressed to evaluate the potential of resistance drilling as an indirect method to measure density or specific gravity of dry wood. Some early studies demonstrated that there was a strong linear correlation between the mean drilling resistance and gross density of dry wood (Görlacher and Hättich 1990; Rinn et al. 1996). More recent studies on structural wood members also showed moderate to strong relationships between measured resistance values and wood density $\left(r^{2}=0.67\right.$ reported by Ceraldi et al. 2001, $r^{2}=0.44$ reported by Zhang et al. 2009, $r^{2}=0.89$ reported by Park et al. 2006, $r^{2}=0.93$ reported by Bouffier et al. 2008, $r^{2}=0.62-0.78$ reported by Sharapov and Chernov 2014).

There has also been a growing interest in using the resistance drilling method for forest genetics field tests. In a tree genetic improvement program, Isik and $\mathrm{Li}$ (2003) evaluated the use of the Resistograph ${ }^{\circledR}$ tool for rapid assessment of relative wood density of live loblolly pine trees in progeny trials. A total of 1477 trees were sampled from 14 full-sib families of loblolly pine across the four test sites. They reported strong correlations among average drilling resistance values and wood density and strong genetic control at the family level. However, individual phenotypic correlations were found to be relatively weak. Similar results have also been reported by Gantz (2002), Charette et al. (2008), Gwaze and Stevenson (2008), and Eckard et al. (2010).

In a recent study, Oliveira et al. (2017) evaluated the use of resistance drilling for assessing wood-specific gravity of young Eucalyptus trees for pulpwood production. The genetic materials used consisted of 50 34-month-old and 50 62month-old trees from Eucalyptus grandis Hill ex Maiden $\times$ Eucalyptus urophylla S.T. Blake clonal plantations. It was found that drill penetration depth had a significant effect on the relationship between average resistance amplitude and specific gravity. They observed a clear trend of weakening correlation as the drill penetration depth increased (Fig. 8), which could be attributed to the increased friction acting on the drill shaft. When a needle drill bit cuts through wood, wood chips remain in the drilling channel causing friction on the rotating needle shaft (Rinn 2012). The spade-type needle drill bit used in resistance drilling measurements typically has a 3-mm-wide triangular shape cutting head which is twice the diameter of the needle shaft $(1.5 \mathrm{~mm})$. The drill bit is designed to reduce the shaft friction during resistance drilling measurements. The shaft friction was reported to be minimal in drilling wood of softwood species (Rinn et al. 1996), but found to be significant in drilling wood of some tropical species such as Eucalyptus (Nutto and Biechele 2015; Oliveira et al. 2017). It was recommended that average resistance amplitude over a one-half-diameter drilling (from bark to pith) should be used for assessing wood-specific gravity of Eucalyptus trees instead of a whole-diameter drilling (Oliveira et al. 2017).

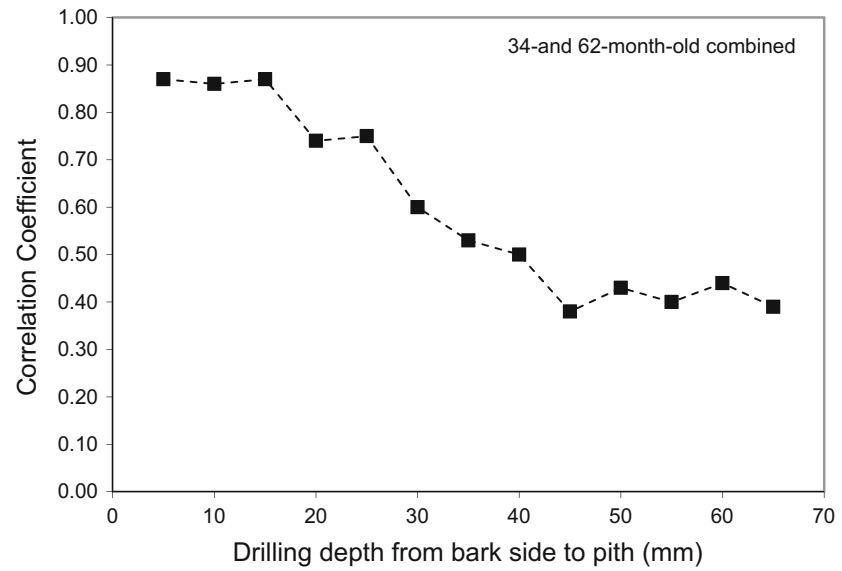

Fig. 8 Correlation coefficient for the relationship between measured drilling resistance (expressed as amplitude in resistance profile) and specific gravity of 34- and 62-month-old Eucalyptus grandis $\times$ Eucalyptus urophylla trees as affected by the drilling depth (from Oliveira et al. 2017, with permission) 


\section{Discussion}

Since the 1960s, the use of increment borers to collect core samples at breast height has become the standard method for obtaining intrinsic wood properties in standing trees. An increment core can provide a complete wood sample if it stretches from the pith to the bark and is only limited by the length of the borer and one's ability to extract an adequate core. Borer diameters range from 4 to $12 \mathrm{~mm}$, with the larger diameters giving the best samples when larger quantities of wood are required (Jozsa 1988; Grissino-Mayer 2003; Williamson and Wiemann 2010). Larger-diameter borers $(12 \mathrm{~mm}$ ) cause less compaction because the area to volume ratio of the wood sample is smaller, and larger samples are easier to measure. However, larger-diameter borers require disproportionally greater expenditures of energy to extract cores, so limiting the depth of penetration to only that required to obtain an adequate sample is desirable. For most purposes, it is desirable to bore in a radial line to the pith. This is sometimes difficult because trees are not perfectly round and human operation error may cause the core to be off-center.

Increment coring is by far the most widely used sampling technique to obtain wood density information in standing trees. Knowledge of within-tree patterns has allowed the use of outer wood values for stem selection in breeding programs and for preharvest assessments (Cown 2006; Kimberley et al. 2015). Compared with the traditional destructive sampling method of cutting disks, the use of an increment borer to extract trunk tissue is considered an economically viable option to minimize the workload. In addition, increment cores allow specific biological zones (e.g., the inner 10 rings or the outer 10 rings) to be identified for study and ensure valid comparisons when properties vary with tree age. However, increment coring will always have potential to damage the trunk of the cored trees and incur some risk of negative impacts on tree health. For example, boring in a veneer-quality black cherry tree will lower the value of the butt veneer log and is therefore considered destructive. Also, bore holes can be the entrance source for decay and disease (Hart and Wargo 1965). In addition, for many applications such as tree improvement programs and large-scale wood quality studies, where potentially hundreds and even thousands of trees must be sampled for wood density information, increment coring is time consuming and expensive. A rapid field-type nondestructive method is becoming increasingly important for various research programs and forest operations.

The torsiometer method still relies on an increment borer in the field, although it greatly reduces the laboratory workload. The equipment is not expensive; however, measurement requires insertion and removal of an increment borer, which causes significant damage to trees and introduces an extra source of error related to the condition of the cutting edge. Splitting can occur at the site of the boring which may produce added measurement variability. There are also problems in operation caused by varying forces applied to the tool handles by different operators, as well as potential operator fatigue that could also affect results.

The use of the Pilodyn method has been explored more extensively than that of the torsiometer method. Many field trials proved that Pilodyn has considerable advantages over both traditional increment core and torsiometer methods. Pilodyn testing typically leaves a 2.5 -mm-diameter hole up to $20 \mathrm{~mm}$ deep whereas an increment borer used for extracting a 5-mm-diameter core leaves a channel about $11 \mathrm{~mm}$ in diameter, and at least $38 \mathrm{~mm}$ deep when a torsiometer is used. Because the pin being injected into a tree in Pilodyn testing is smaller in diameter than an increment borer, the damage done is significantly smaller. Second, the operation of Pilodyn testing is much more rapid than that of the torsiometer. This reduces field time considerably. However, the wood being evaluated in Pilodyn testing is only the outmost rings, often entirely sapwood, which is probably not representative of the stem's mean density. Sapwood often lacks extraneous materials and typically has a higher moisture content than adjacent heartwood, both of which result in lower density (Panshin and de Zeeuw 1980). The main application of Pilodyn in wood density assessment has been in the field of tree breeding, where density is considered to be a trait worth improving (Wilcox et al. 1975). Pilodyn is considered by many researchers to be a viable tool in tree improvement trials in terms of efficiency and productivity, particularly in young stems where bark removal is easy and rapid (Chen et al. 2015). However, in older trees, Pilodyn is relatively time-consuming when the bark is thick.

A disadvantage of both the Pilodyn and torsiometer instruments is their relatively insensitive scales and the consequent potential errors that result from interpreting between narrow limits (Cown 1978). In practice, it is unrealistic to record Pilodyn results at smaller than $0.5-\mathrm{mm}$ intervals, despite the fact that $1 \mathrm{~mm}$ represents about $20 \mathrm{~kg} / \mathrm{m}^{3}$. As a result of this insensitivity, it is absolutely essential that the bark be removed prior to testing, since bark thickness can vary appreciably from tree to tree.

The nail withdrawal method was sought as an alternative to both the torsiometer and Pilodyn in an endeavor to overcome their disadvantages of insensitivity in scale. The nail withdrawal apparatus developed by Nicholls (1985) was able to achieve the repeatability of pressure readings equivalent to $2 \mathrm{~kg} / \mathrm{m}^{3}$, which is $25 \%$ of that for Pilodyn or the torsiometer. The correlation coefficients for the linear relationship between the withdrawal resistance and wood density are similar to that for Pilodyn (Cown 1978, 1981) and the torsiometer (Nicholls and Roget 1977). The damage to the tree is similar to that caused by testing with Pilodyn and less than that caused by the torsiometer. Although the results of nail withdrawal tests were considered promising by Nicholls (1985), there are 
underlying technical issues that hinder the use of the apparatus in trees. Under all possible conditions of use (species, climate, temperature, moisture content, nail type, etc.), the withdrawal resistance of nails in standing trees could vary as widely as that in dry wood.

The resistance drilling method is relatively new in comparison to the other field methods discussed. Several commercial tools are now available for field use, including Resistograph® (Rinntech E.k., Heidelberg, Germany), IML-RESI Systems (IML Instrumenta Mechanik Labor System GmbH, Wiesloch, Germany), and a digital microprobe (Sibert Technology Ltd., Surrey, England). Compared with all other methods, resistance drilling tools are easy to handle in the field, data collection and analysis have lower cost and are more rapid, and measurement results (density profiles) are less affected by operators. Additionally, the needle is driven into trees at a fixed feed rate and leaves a 3.0-mm-diameter hole that is almost invisible. The rotational speed and feed rate of the drill bit can be adjusted to suit different species. Resistance drilling does not require the bark to be removed, so it is less damaging to young trees. Commercial resistance drilling devices typically have different drilling depths. When properly selected, a resistance drilling tool can evaluate a tree stem from bark to pith or the entire cross section diametrically, from bark to bark. In contrast, a Pilodyn needle penetrates only the first few outer rings.

Despite good resolution of resistance profiles and strong correlation with wood density, the application of the drilling resistance technique has so far mostly been found in the areas of urban tree decay detection and structural timber condition assessment. Resistance drilling measurement has now been incorporated into routine field inspection procedures recommended for both comprehensive tree hazard evaluation and structural timber condition assessment. Recent studies indicated that the use of the resistance drilling method can potentially be extended into tree genetic improvement and wood quality survey programs where hundreds or even thousands of trees must be sampled for wood density information. One of the key issues with the resistance drilling method is related to the internal friction as the drill bit cuts deep into the tree. Because of the increased friction acting on the drill shaft, the accuracy of the relative resistance measurement can be affected. As a consequence, the predictive power of the amplitude parameter obtained from a resistance profile can be substantially reduced, especially in trees of larger diameter and higher wood density. A possible solution would be to conduct partial resistance drilling measurements on tree stems instead of drilling through the whole diameter and assess the outer wood density of standing trees. If the outer wood density of a tree can be accurately determined through partial resistance drilling measurements, then the wood density models developed for the increment coring method can be used to predict the disk or whole tree density using the outer wood density values. The validity of this partial resistance drilling approach needs to be tested in future research.

With regards to the field implementation of resistance drilling tools, there were some speculations that environmental, operator, and instrument factors might affect the accuracy of resistance drilling measurements. In a study designed to quantify the sensitivity of the drilling tool to various environment and instrument factors, Ukrainetz and O'Neill (2010) found that the density index is sensitive to operator movement, tree moisture content, air temperature, and proximity of the sampling location to knots. Nonetheless, by ensuring that an operator remains steady while drilling, sampling only live trees, testing only when ambient temperature is above freezing, and avoiding knots, measurement error can be minimized.

When selecting appropriate field nondestructive tools for determining wood density or specific gravity of standing trees, it is important to note that the solution must meet the needs of practicing foresters, and reasonable estimates of average values with measurable errors will be more useful than expensive, highly technical procedures of greater accuracy. While direct wood density measurements are often taken as the benchmark, it must be noted that wood density varies with stand age, site, silvicultural treatments, and genetics. A sound sampling strategy is critical in any wood density survey to ensure the validity of the method used. In general, the reasons for a nondestructive sampling procedure may include (1) assessing the wood quality of forest resource available at a regional to a compartment level; (2) examining the effects of site, climate, or silvicultural treatments on wood quality; and (3) assessing young trees for genetic improvement. For each of these reasons, different numbers of tree samples and sampling procedures will need to be carefully designed. A detailed discussion of nondestructive sampling methods can be found in Downes et al. (1997).

\section{Conclusions}

The basic increment core method has dominated research for over a half century and has been used as a standard method for assessing wood quality of forest resources, determining biomass of ecosystems, and investigating climate history through dendrochronological analysis. Comprehensive wood density models have been developed for commercially important species that allow the use of outer wood cores and knowledge of internal tree density distribution for fairly accurate prediction of the density of major tree components. With the development of SilviScan and NIR spectroscopy instruments, more wood and fiber properties can be obtained from a single increment core sample, allowing comprehensive wood quality evaluation of plantation trees for genetic improvement, forest management, and optimal wood utilization. However, for many users or in many applications, increment core sampling 
and subsequent laboratory analysis are time consuming and expensive. A rapid field-type nondestructive method is needed in various research programs and forest operations.

Studies on torsiometer, Pilodyn, and nail withdrawal methods had very limited success. The use of the torsiometer and Pilodyn requires bark removal, and measurements are limited to a short penetration depth $(40 \mathrm{~mm}$ with torsiometer, up to $20 \mathrm{~mm}$ with Pilodyn). Both methods have a disadvantage of relative insensitivity of the measurement scales and subsequent potential errors in interpreting between narrow limits. The nail withdrawal method was reported to reach a higher sensitivity than the torsiometer and Pilodyn. However, the scientific data is limited and there are underlying technical issues related to species, density, nail type, nail diameter, and surface condition of the nails, which really hinder its application in trees.

The resistance drilling method has considerable advantages over the torsiometer, nail withdrawal, and Pilodyn methods in terms of causing less damage to trees, faster operation, and having a more sensitive measurement scale. One of the factors that currently hinder the use of the resistance drilling tool for rapid wood density determination in trees is the internal friction encountered by the drill shaft as it cuts deeply into the tree stem. A partial resistance drilling approach coupled with knowledge of internal tree density distribution may offer an alternative to the currently widely used increment coring technique.

Acknowledgement This study was conducted under the cooperative research agreement between the Northeast Forestry University and the USDA Forest Service, Forest Products Laboratory.

\section{Compliance with ethical standards}

Funding This study is supported in part by the National Natural Science Foundation of China (Grant no. 31600453), Natural Science Foundation of Heilongjiang Province, China (Grant no. C201403), and the USDA National Institute of Food and Agriculture (NIFA) Tribal Colleges Research Grants Program (Grant no. 2010-38424-21329).

\section{References}

Allison RB, Wang X (2015) Nondestructive testing in the urban forest. In: Ross RJ (ed) Nondestructive Evaluation of Wood, $2^{\text {nd }}$ edn. General Technical Report FPL-GTR-238. U.S. Department of Agriculture, Forest Service, Forest Products Laboratory, Madison, WI, pp 77-86

Bagge S (1977) Forskellige ædelgranproveniensers vedkvalitet (med særligt henblik $p$ rumtæthedsvariationen og $m$ ling af rumtætheden med slaghammer). Copenhagen

Blair RB, Zobel B, Hitchings RC, Jett JB (1976) Pulp yield and physical properties of young loblolly pine with high density juvenile wood. Appl Polym Symp 28:435-444

Bouffier L, Charlot C, Raffin A, Rozenberg P, Kremer A (2008) Can wood density be efficiently selected at early stage in maritime pine (Pinus pinaster Ait.)? Ann For Sci 65:106-113
Carter P, Briggs D, Ross RJ, Wang X (2005) Acoustic testing to enhance western forest values and meet customer wood quality needs. General Technical Report PNW-GTR-642, Productivity of Western Forests: A Forest Products Focus. USDA Forest Service, Pacific Northwest Research Station, Portland, Oregon, pp 121-129

Carter P, Wang X, Ross RJ (2013) Field application of processor head acoustic technology in forest harvest operations. Proceedings: 18th International Nondestructive Testing and Evaluation of Wood Symposium. General Technical Report FPL-GTR-226. Madison, WI: U.S. Department of Agriculture, Forest Service, Forest Products Laboratory, pp 7-14

Ceraldi C, Mormone V, Ermolli ER (2001) Resistographic inspection of ancient timber structures for the evaluation of mechanical characteristics. Mater Struct 34:59-64

Chan JM, Raymond CA, Walker JC (2010) Non-destructive assessment of green density and moisture condition in plantation-grown radiata pine (Pinus radiata D. Don.) by increment core measurements. Holzforschung 64:521-528

Chantre G, Rozenberg P (1997) Can drill resistance profiles (Resistograph) lead to within-profile and within-ring density parameters in Douglas-fir wood? In: Zhang SY, Gosselin R, Chauret G (eds) Proc. of CTIA - International Union of Forestry Research Organizations (IUFRO) International wood quality workshop: timber management toward wood quality and end-product value. Forintek Canada Corp., Sainte-Foy, Quebec, Canada, pp 41-47

Charette P, Lu P, Tang F, Zhang SY (2008) Evaluation of the resistograph for wood density estimate and the use of multi-trait selection index for genetic selection in jack pine. In: Simpson JD (ed) Proceedings of the $31^{\text {st }}$ Meeting of the Canadian Forest Genetics Association: Adaptation and Conservation in the Era of Forest Tree Genomics and Environmental Change, Quebec City, Quebec, 25-28 August 2008. Natural Resources Canada, Canadian Forest Service, Fredericton, N.B, p 88

Chen Z, Karlsson B, Lundqvist S, García Gil MR, Olsson L, Wu HX (2015) Estimating solid wood properties using Pilodyn and acoustic velocity on standing trees of Norway spruce. Ann For Sci 72:499 508. doi:10.1007/s13595-015-0458-9

Cown DJ (1978) Comparison of the Pilodyn and torsiometer methods for the rapid assessment of wood density in living trees. NZJ For Sci 8: 384-391

Cown DJ (1979) Evaluation of the Pilodyn wood tester for the assessment of wood density in standing trees: status report. IUFRO Working Party S2.03.09 Australia. Breeding Pinus radiata Newsletter No. 3

Cown DJ (1981) Use of the Pilodyn wood tester for estimating wood density in standing trees - influence of site and tree age. Paper presented to XVII IUFRO World For. Congress, Kyoto. N.Z. For. Serv. For. Res. Inst. Bull. No. 13

Cown DJ (2006) Wood quality in standing timber - evolution of assessment methods in plantations. In: Kurjatko S, Kúdela J, Lagaňa R (eds) Proceedings of the $5^{\text {th }}$ IUFRO Symposium "Wood Structure and Properties '06". September 3-6, 2006. Sliac-Sielnica, Slovakia

Cown DJ, Clement BC (1983) A wood densitometer using direct scanning with x-ray. Wood Sci Technol 17:91-99

Dean HG, French J, Tibbits WN (1990) Variation in pulp making characteristics in a field trial of Eucalyptus globulus. In: The $44^{\text {th }}$ Annual Appita General Conference, 2-6 April 1990. Rotorua, New Zealand. Appita, Melbourne, Australia, B24:1-33

Downes GM, Hudson IL, Raymond CA, Dean GH, Michell AJ, Schimleck LR, Evans R, Muneri A (1997) Sampling plantation Eucalypts for wood and fibre properties. CSIRO, Melbourne

Eberhardt TL, Samuelson LJ (2015) Collection of wood quality data by X-ray densitometry: a case study with three southern pines. Wood Sci Technol 49:739-753 
Eckard TJ, Isik F, Bullock B, Li B, Gumpertz M (2010) Selection efficiency for solid wood traits in Pinus taeda using time-of-flight acoustic and micro-drill resistance methods. For Sci 56:233-241

Evans R, Ilic J (2001) Rapid prediction of wood stiffness from microfibril angle and density. Forest Prod J 51:53-57

Evans R, Kibblewhite RP (2002) Controlling wood stiffness in plantation softwoods. In: Beall FC (ed.), The $13^{\text {th }}$ International Symposium on Nondestructive Testing of Wood, University of California, August 2002. Forest Products Society, pp 67-74.

Forest Products Laboratory (FPL) (1965) Nail-withdrawal resistance of American woods. US Forest Service Research Note FPL-093. U.S. Department of Agriculture, Forest Service, Forest Products Laboratory, Madison, Wisconsin $5 \mathrm{p}$

Gantz CH (2002) Evaluating the efficiency of the Resistograph to estimate genetic parameters for wood density in two softwood and two hardwood species. MSc Thesis, North Carolina State University, Raleigh, NC, $88 \mathrm{p}$

Gao S, Wang X, Brashaw BK, Ross RJ, Wang L (2012) Rapid assessment of wood density of standing trees with nondestructive methods-A review. In: Proceedings, BMSE 2012 International Conference on Biobase Material Science and Engineering, October 21-23, 2012, Changsha, China. pp 262-267

Glass SV, Zelinka SL (2010) Moisture relations and physical properties of wood. Wood Handbook, chapter 4. US Forest Service Forest Products Laboratory, Madison, Wisconsin

Görlacher R, Hättich R (1990) Untersuchung von altern Konstruktionsholz: Die Bohrwiderstandsmessung. Bauen mit Holz 92:455-459

Gough G, Barnes RD (1984) A comparison of three methods of wood density assessment in a Pinus elliottii progeny test. South African For J 128:22-25

Greaves BL, Borallho NMG, Raymond CA, Farrington A (1996) Use of a Pilodyn for the indirect selection of basic density in Eucalyptus nitens. Can J For Res 26:1643-1650

Grissino-Mayer HD (2003) A manual and tutorial for the proper use of an increment borer. Tree-Ring Research 59:63-79

Guller B, Guller A, Kazaz G (2012) Is resistograph an appropriate tool for the annual ring measurement of Pinus brutia? NDE for Safety/ DEFEKTOSKOPIE 2012:89-94

Gwaze D, Stevenson A (2008) Genetic variation of wood density and its relationship with drill resistance in shortleaf pine. South J Appl For 32:130-133

Harris JM, McConchie DL, Young GD (1976) Wood density assessment by measuring torsion required to turn an increment borer in standing trees. N.Z. For. Serv. For Res. Inst. For. Prod. Lab. Rep. No. FP. WQ 23 (unpubl.)

Hart JH, Wargo PM (1965) Increment borer wounds - penetration points for Ceratocystis fagacearum. J For 63:38-39

Helms D, Niemz P (1994) New applications of the drill resistance method for quality evaluation of wood and wood products. In: Pellerin R, McDonald KA (eds) Proceedings of the 9th International Symposium on Nondestructive Testing of Wood, 1993, Seattle. Washington, Washington State University, Madison, WI, pp 95-102

Henningsson B, Nilsson T, Hoffmeyer P, Friis Hansen H, Schmidt L, Jakobsson S (1976) Soft rot in utility poles salt-treated in the years 1940-1954. Swedish Wood Preservation Institute, Report No. 117E, Stockholm, Sweden

Hoffmeyer P (1978) The Pilodyn instrument as a non-destructive tester of the shock resistance of wood. Paper presented at the non-destructive testing meeting, Vancouver, Wash, Aug. 1978. $21 \mathrm{p}$

Isik F, Li B (2003) Rapid assessment of wood density of live trees using the Resistograph for selection in tree improvement programs. Can J For Res 33:2427-2435

Jozsa L (1988) Increment core sampling techniques for high quality cores. Special publication No. SP-30, Forintek Canada Corporation. $26 \mathrm{p}$
Kandeel SAE, Bensend DW (1969) Structure, density, and shrinkage variation within a silver maple tree. Wood Science 1:227-237

Kimberley MO, Cown DJ, McKinley RB, Moore JR, Dowling LJ (2015) Modeling variation in wood density within and among trees in stands of New Zealand-grown radiata pine. N Z J For Sci 45:22. doi:10.1186/s40490-015-0053-8

King JN, Yeh FC, Heaman JC, Dancik BP (1988) Selection of wood density and diameter in controlled crosses of coastal Douglas-fir. Silvae Genet 37:152-157

Maeglin RR (1979) Increment cores: how to collect, handle, and use them. General Technical Report FPL-GTR-25. U.S. Department of Agriculture, Forest Service, Forest Products Laboratory, Madison, WI $18 \mathrm{p}$

Mattheck C, Bethge K, Albrecht W (1997) How to read the results of resistograph M. Arboricultural Journal 21:331-346

Micko MM, Wang EIC, Taylor FW, Yanchuk AD (1982) Determination of wood specific gravity in standing white spruce using a Pilodyn tester. For Chron 58:178-180

Moura VPG, Barnes RD, Birks JS (1987) A comparison of three methods of assessing wood density in provenances of Eucalyptus camaldulensis Dehnh. and other Eucalyptus species in Brizal Australian Forest Research 17:83-90

Nicholls JMP (1985) A new method for determining wood density in the standing tree. Australian Forestry Research 15:195-206

Nicholls JMP, Roget DK (1977) Tests on a field method for the determination of wood density. Aust For 40:144-150

Nutto L, Biechele T (2015) Drilling resistance measurement and the effect of shaft friction - using feed force information for improving decay identification on hard tropical wood. In: Ross RJ, Gonçalves R, Wang X (eds) Proceedings of the 19th International Nondestructive Testing and Evaluation of Wood Symposium. General Technical Report FPL-GTR-239. U.S. Department of Agriculture, Forest Service, Forest Products Laboratory, Madison, WI, pp 154-161

Oliveira JT, Wang X, Vidaurre GB (2017) Assessing specific gravity of young Eucalyptus plantation trees using a resistance drilling technique. Holzforschung.71(2): 137-145

Palmer DJ, Kimberley MO, Cown DJ, McKinley RB (2013) Assessing prediction accuracy in a regression kriging surface of Pinus radiata outerwood density across New Zealand. For Ecol Manag 308:9-16

Panshin AJ, de Zeeuw C (1980) Textbook of wood technology. McGrawHill Book Company, New York

Park CY, Kim SJ, Lee JJ (2006) Evaluation of specific gravity in post member by drilling resistance test. Mokchae Konghak 34:1-9

Paul BH, Baudendistel ME (1956) A field method of determining specific gravity by use of increment cores or auger chips. Forest Products Laboratory Report No. $1587,8 \mathrm{p}$

Polge H, Keller R (1970) Première appréciation de la qualité du bois en forêt par utilization d'un Torsiomètre. Ann Sci Forest 27:197-223

Pressler MR (1866) Der forstliche Zuwachsbohrer neuester Construction und dessen praktische Bedeutung und Anwendung für die forstliche Forschungs-, Taxations-, Pflege- und Nutzungs-Technik. Tharander Jahrbuch. 17, III: 113-209

Rinn, F (1988) A new method for measuring tree-ring density parameters. Physics diploma thesis, Institute for Environmental Physics, Heidelberg University

Rinn F (1989) Eine neue Bohrmethode zur Holzuntersuchung. HolzZentralblatt 34:529-530

Rinn F (1990) Device for material testing, especially wood inspection by drill resistance measurements. German Patent 4122494

Rinn F (2012) Basics of micro-resistance drilling for timber inspection. Holztechnologie 53:24-29

Rinn F, Schweingruber FH, Schar E (1996) Resistograph and x-ray density charts of wood comparative evaluation of drill resistance profiles and x-ray density charts of different wood species. Holzforschung 50:303-311 
da Rosado SCS, Brune A, de Oliveira LM (1983) Avaliacão da densidade básica da madeira de árvores em pé. Rev Arvore 7:147-153

Ross RJ, Brashaw BK, Wang X, Pellerin RF (2004) Wood and timber condition assessment manual. Forest Products Society, Madison, WI

Saez JL, Corona C, Berger F (2008) Use of resistograph for dendrogeomorphological analysis of avalanche impacts (massif de l'Oisans, France). Geophysical Research Abstracts Vol. 10, EGU2008-A-01311. SRef-ID: 1607-7962/gra/EGU2008-A-01311

Schweingruber EH (2001) Dendroökologische Holzanatomie: Anatomische Grundlagen der Dendrochronologie. Paul Haupt Verlag, Berne $472 \mathrm{p}$

Sharapov ES, Chernov VY (2014) Comparative analysis of wood density techniques determination with using X-ray and device for drilling resistance measurements. Moscow State Forest University Bulletin Lesnoy vestnik 2:89-95

Sprague JR, Talbert JT, Jett JB, Bryant RL (1983) Utility of the Pilodyn in selection for mature wood specific gravity in loblolly pine. For Sci 29:696-701

Taras MA, Wahlgrn HE (1963) A comparison of increment core sampling methods for estimating tree specific gravity. US Forest Service Research Paper SE-7, $16 \mathrm{p}$

Taylor FW (1981) Rapid determination of southern pine specific gravity with a Pilodyn tester. For Sci 27:59-61

Tian X, Cown DJ (1995) Modeling of wood properties in New Zealand. In: Klitscher K, Cown DJ, Donaldson L (eds) Wood quality workshop 95. FRI bulletin 201. Rotorua, New Zealand, Forest Research Institute, pp 72-81

Tian X, Cown DJ, McConchie DL (1995) Modeling of radiata pine wood properties. Part 2: wood density. N Z J For Sci 25:214-230

Ukrainetz NK, O'Neill GA (2010) An analysis of sensitivities contributing measurement error to resistograph values. Can J For Res 40: 806-811

Wahlgren HE, Fassnacht DL (1959) Estimating tree specific gravity from a single increment core. USDA Forest Service Forest Products Laboratory report No. 2146, $24 \mathrm{p}$

Wang X, Allsion RB (2008) Decay detection in red oak trees using a combination of visual inspection, acoustic testing, and resistance microdrilling. Arboricult Urban For 34:1-4

Wang SY, Chiu CM, Lin CJ (2003) Application of the drilling resistance method for annual ring characteristics: evaluation of Taiwania (Taiwania cryptomerioides) trees grown with different thinning and pruning treatments. J Wood Sci 49:116-124

Wang SY, Lin CJ (2001) Application of the drill resistance method for density boundary evaluation of earlywood and latewood of Taiwania (Taiwania cryptomerioides Hay.) plantation. Taiwan Forest Sci 16:197-200
Wang X, Ross RJ, McClellan M, Barbour RJ, Erickson JR, Forsman JW, McGinnis GD (2001) Nondestructive evaluation of standing trees with a stress wave method. Wood \& Fiber Sci 33:522-533

Wang X, Ross RJ, Carter P (2007a) Acoustic evaluation of wood quality in standing trees: part 1. Acoustic wave behavior in standing trees. Wood and Fiber Sci 39:28-38

Wang X, Carter P, Ross RJ, Brashaw BK (2007b) Acoustic assessment of raw forest materials - a path to increased profitability. Forest Prod J 57:6-14

Wiemann MC, Williamson GB (2012a) Density and specific gravity metrics in biomass research. General Technical Report FPL-GTR-208. Madison, WI: U.S. Department of Agriculture, Forest Service, Forest Products Laboratory, $6 \mathrm{p}$

Wiemann MC, Williamson GB (2012b) Testing a novel method to approximate wood specific gravity of trees. For Sci 58:577-591

Wiemann MC, Williamson GB (2013) Biomass determination using wood specific gravity from increment cores. General Technical Report FPL-GTR-225. Madison, WI: U.S. Department of Agriculture, Forest Service, Forest Products Laboratory, $7 \mathrm{p}$

Wiemann MC, Williamson GB (2014) Wood specific gravity variation with height and its implications for biomass estimation. Research Paper FPL-RP-677. Madison, WI: U.S. Department of Agriculture, Forest Service, Forest Products Laboratory, $9 \mathrm{p}$

Wilcox MD, Thulin IJ, Vincent TG (1975) Selection of Pinus radiata clones in New Zealand for commercial planting from cuttings. N.Z. For. Serv. For. Res. Inst. Prod. For. Div., Genetics and Tree Improvement Report No. 72

Williamson GB, Wiemann MC (2010) Measuring wood specific gravity...correctly. Am J Bot 97:519-524

Wu SJ, Xu JM, Li GY, Risto V, Lu ZH, Li BQ, Wang W (2010) Use of the Pilodyn for assessing wood properties in standing trees of Eucalyptus clones. J For Res 21:68-72

Young, GD (1977) Effect of wood age, species and site on regressions relating wood density to torsion required to turn an increment borer. N.Z. For. Serv. For. Res. Inst. Forest Products Division Report No. FP/WQ14

Zhang SY (1997) Wood quality: its definition, impact, and implications for value-added timber management and end uses. In: Zhang SY, Gosselin R, Chauret G (eds) Timber management toward wood quality and end uses, Proceedings of the CTIA/IUFRO International Wood Quality Workshop, August 18-22, 1997, Quebec City, 23 p

Zhang H, Guo Z, Su J (2009) Application of a drill resistance technique for rapid determining wood density. Progress of machining technology. Key Eng Mater 407-408:494-499

Zobel BJ, van Buijtenen JP (1989) Wood variation - its causes and control. Springer series in wood science. Springer New York Inc., New York 